\title{
Improvement Efforts III through Content Control Services with Role Playing Techniques in FKIP Products and Counseling Christian University of Indonesia
}

\author{
Melda Rumia Rosmery Simorangkir
}

\begin{abstract}
Low self-confidence is still a problem that is quite alarming among early adult Indonesian women. There are still many early adults who make beauty the root of their anxiety, not a source of self-confidence. Dove Girl Beauty Confidence Report in kompas.com shows that 54 percent of early adult women in the world do not have high self-confidence. In fact, 7 out of 10 of them in Indonesia withdraw from important activities not confident. The Assistant Deputy for the Fulfillment of the Rights of the Child for Education, Creativity and Culture of the Ministry of Women's Empowerment and Child Protection, Elvi Hendrani, improper parenting from parents also has a major influence in reducing children's self-confidence. for early adults. However, more important recognition from parents and teachers. The results of the research on the provision of content mastery services with the role playing technique for early adult students can be concluded: (1) the confidence of early adult students before joining the content mastery service with role playing techniques is in the low category. This is indicated by the indicators of student self-confidence on average in the low category; (2) self-confidence of early adult students after participating in content mastery services with role playing techniques in the high category. This is indicated by the indicators of student self-confidence on average in the high category; (3) student self-confidence has increased after getting treatment in the form of content mastery services with role playing techniques. A significant increase was seen from the Wilcoxon test results. The Wilcoxon test results show that $Z$ count is smaller than $Z$ table, so the hypothesis is accepted. The indicator that experienced the highest increase was an indicator of optimism during the period of body changes.
\end{abstract}

Keywords: Self-confidence, Content Mastery Service, Role Play Technique.

\section{INTRODUCTION}

During the development of children mid and late, physical growth occurs at a slower rate than during infancy and early childhood. Gross motor skills become more refined and more coordinated, as well as fine motor skills. Like developments in childhood, the development of late adolescence is characterized by interactions between genetic,

Revised Manuscript Received on September 22, 2019

Melda Rumia Rosmery Simorangkir, Bachelor's Degree Lecturer in Guidance and Counseling Study Program, Teaching and Education Faculty, Christian University of Indonesia biological, environmental, and social factors. During childhood, adolescents spend thousands of hours interacting with their parents, peers, and teachers, now it's time for them to be confronted with dramatic biological changes, new experiences, and new developmental tasks. When the fourth semester students came from various regions with the aim of studying at Christian University of Indonesia, 10 of the 12 first semester female students had never come to visit Jakarta. Based on the results of the interviews, the students were generally shocked and had difficulty adjusting. Regional languages that are inherent in them make it very difficult for them to get used to using Indonesian. Likewise, the appearance, manner of dress and preening are also serious concerns for female students, especially those who come from outside Jakarta.

The attitude of the general public that is formed towards adolescents and early adults is the result of a combination of personal experience. Many adults measure their perceptions of adolescents and early adults based on their memories of their own experiences when they are teenagers. Lerner et al in Santrock (2011: 403) late adolescence and early adulthood experienced by women trying to negotiate with regard to the time needed to finally succeed in becoming a mature deawa, but quite a lot less successful. The differences in ethnicity, culture, gender, socio-economy, age, and lifestyle greatly influence the crossing of life. Young women who enter early adulthood when they occupy the fourth semester on the college bench are very concerned about their bodies and develop images about their bodies. Generally, they compare their bodies with their friends' bodies. Women are generally dissatisfied with their body condition due to the increasing amount of fat, in contrast to men being more satisfied with the early adulthood they passed due to increased muscle mass. For this reason, many of the students who are trying to do various ways to increase their confidence. They start looking for their physical needs from Instagram, Facebook, Google or other social media. Various tips are followed to achieve maximum self-confidence, so that sometimes they torture them a lot and make them not focus on attending lectures. As a supervisor, one of my tasks is to restore their confidence. This is certainly not easy, various approaches must be carried out in accordance with the stages of their

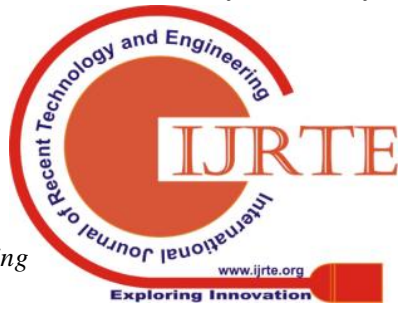


development so that they do not take offense and close themselves. I tried the approach in counseling to later become part of the research.

Sustein (2008) in Suntrock (2011: 425) adolescence is a period where someone is faced with a dilemma situation, they can experience confusion between choosing good and bad, so they do not experience rejection with their social environment.

In general, fourth semester students build self-confidence in various ways to be accepted in the university environment. They assume that with a tall, slim, white body, unraveled hair is their main capital to be accepted in their environment. As we get older, they begin to cover the brand's shortcomings with various make up methods. Various make up tutorials are seen and started to be applied. Sources that they can see directly or even through social media or YouTube. Psychologically it is realized or not it can also be considered part of learning. The process of behavior change they do is part of the results of interaction with their environment in meeting their life needs to be confident and accepted in the environment.

The purpose of this study is to achieve self-confidence in students in carrying out assignments in class, in accepting the risks of actions they take, believe in apologizing for the mistakes they have taken, and expressing their opinions. So, the efforts made to increase the confidence of fourth semester students are by content services with role playing techniques. Researchers in this case as academic supervisors who play a considerable role as long as students' study with content services using role playing techniques. The content service itself according to Prayitno in Thohirin (2011: 158) reveals that content services themselves are assistance services provided to students both individually and in groups so that they master certain abilities or competencies carried out through learning activities.

In applying content services, researchers as academic supervisors have a role as counselors who uphold the principle of confidentiality in order to see more deeply the causes of a lack of student confidence. So that when efforts to increase self-confidence carried out by researchers can take place well and on target this is because students have built trust with researchers and this makes it easy to conduct guidance. Content services with role playing techniques are expected to increase female students' confidence, especially in the fourth semester.

\section{A. Confidence}

Santrock (2011) reveals that self-confidence is a very evaluative role that is entirely present in oneself. Self-confidence is part of an individual's self-image and how an individual respect himself. Individuals who have confidence can be seen from their ability to initiate, be creative, optimistic about things, consciously realize their mistakes and shortcomings to be improved. Self-confidence possessed by individuals is needed to support individuals in maximizing their abilities so that they are not easily hesitant in making decisions or actualizing their abilities. Teenagers who are not confident will certainly hinder their development both at school, family, and society.

\section{B. Content Services}

Content services are one of the services available in the guidance and counseling of these services carried out both individually and in groups and carried out directly by the counselor. Counselors play an active role as counselors who prepare various materials, provide examples, stimulate, so that guidance students actively follow and undergo the service activities presented. Self-confidence content given to students is presented in the form of interesting stories which will then be played in class by the students. Besides that, researchers also build feedback about material confidence and some role play they will do. Follow-up activities can be carried out in the form of assignments, group discussions, conducting field surveys, action exercises or library studies.

\section{Role Playing Techniques}

Role playing itself is an action directed by researchers who are related to themselves outside of students (others). Role playing is a role playing activity, in this activity students play roles with the theme of activities that intersect directly with their daily activities. In role playing guidance and counseling included in the learning method, students as clients are imaginative playing that is associated with daily activities with the aim of being able to understand themselves and the developing ability to analyze behavior so that they can see which behavior needs to be improved and which needs to be maintained.

\section{RESEARCH METHODS}

The research method that is done is by experiment. Sugiono (2010: 109) revealed that the experimental method serves to look for influences on certain treatments given by researchers but in controlled contexts. Not much different from Arikunto (2009: 3) according to him research in the experimental method aims to find a causal relationship between cause and effect, there is a deliberate factor presented by the researcher as a deception or disturbing factor. That reason is the basis for why researchers are very sure to find out whether there is influence in the effort to increase the confidence of fourth semester students through the use of content services with role playing techniques.

In this study researchers used pre-experiment. Pre experiment with the type of one group pretest and posttest design. In this design, there are two measurement steps until the results of the behavior change are found in the students studied. In the first stage (pretest) the researcher observes and assesses the behavior of students before experiencing acts of content service with the technique of role playing. In the second stage (posttest) the researcher made observations, interviews, evaluations and evaluations after experiencing the first action. The research design is as follows:

Information:

O1: Pretest

Published By Blue Eyes Intelligence Engineerin 
$\mathrm{X}$ : Actions (implementing content services using role playing techniques)

O2: Post test

Table 1: Material Schedule

\begin{tabular}{|c|c|c|}
\hline Meeting & Material & Time \\
\hline I & $\begin{array}{l}\text { Self-confidence in the ability to } \\
\text { complete college assignments } \\
\text { without looking at friends' } \\
\text { answers, confident in } \\
\text { acknowledging mistakes that } \\
\text { have been made. }\end{array}$ & $\begin{array}{l}2 \times 45 \\
\text { minute }\end{array}$ \\
\hline II & $\begin{array}{l}\text { Fostering an optimistic attitude } \\
\text { so as not to overcrowd in class, } \\
\text { able to do the task by believing } \\
\text { in one's own abilities, } \\
\text { understanding deficiencies and } \\
\text { receiving joyfully, convinced } \\
\text { that by apologizing in advance } \\
\text { would improve the situation. }\end{array}$ & $\begin{array}{l}2 \times 45 \\
\text { minute }\end{array}$ \\
\hline
\end{tabular}

Outline of the implementation of the research in the following table:

Table 2: Design of Content Mastery Service Role Playing Techniques

\begin{tabular}{|c|c|c|}
\hline No & Stages & Activities \\
\hline 1 & Preparation & $\begin{array}{l}\text { (a) determine the topic, (b) make the } \\
\text { storyline }\end{array}$ \\
\hline & & $\begin{array}{l}\text { a) creating rapport (good relations), } \\
\text { (b) interviews and question and }\end{array}$ \\
\hline 2 & Implementation & $\begin{array}{l}\text { answer, (c) agreeing to groups, and } \\
\text { (c) giving explanations to the role of } \\
\text { the audience and players. }\end{array}$ \\
\hline & & $\begin{array}{l}\text { (a) express the feeling of being a } \\
\text { player, (b) the plot in the story, (c) }\end{array}$ \\
\hline 3 & Assessment and & the character of the player, (d) assess \\
\hline 3 & Discussion & $\begin{array}{l}\text { the end of the road to the story, (e) } \\
\text { assess the good example that can be } \\
\text { imitated (good behavior) }\end{array}$ \\
\hline 4 & Evaluation & $\begin{array}{l}\text { Evaluating role playing activities } \\
\text { whether or not they have reached the } \\
\text { goal. }\end{array}$ \\
\hline
\end{tabular}

\section{RESEARCH RESULTS AND DISCUSSION}

The results in this study describe student confidence before experiencing action

Table 3: Frequency Distribution of Confidence Early in Pre Test Results

\begin{tabular}{cccc}
\hline $\begin{array}{c}\text { Interval persentase } \\
\text { skor }\end{array}$ & $\mathbf{F}$ & $\boldsymbol{\%}$ & Criteria \\
\hline $90 \%-100 \%$ & 0 & 0 & Very good \\
$70 \%-80 \%$ & 0 & 0 & Well \\
$50 \%-60 \%$ & 2 & 16,6 & Enough \\
$30 \%-40 \%$ & 10 & 83,3 & Bad \\
$10 \%-20 \%$ & 0 & 0 & Very bad
\end{tabular}

$12 \quad 100$

It was known that before being given the content mastery service with role playing techniques, the picture of self-confidence in the third semester students was in the moderate category with a percentage of $16.6 \%$ or a number of 2 female adolescents and a low category with a percentage of $83.3 \%$ or 12 female students.

Table 4: Average Self Confidence Initial Pre Test Results per Indicator

$\begin{array}{ccc}\text { No } \begin{array}{c}\text { Indicator } \\ \text { Self-confidence in the }\end{array} & \text { Percent } & \text { Criteria } \\ \text { ability to complete college } & & \\ \text { assignments without } & & \\ \text { looking at friends' } & 54 \% & \text { Enough } \\ \text { answers, confident in } & & \\ \text { acknowledging mistakes } & & \\ \text { that have been made. } & & \\ \text { Fostering an optimistic } & \\ \text { attitude so as not to } & \\ \text { overcrowd in class, able to } \\ \text { do the task by believing in } \\ \text { one's own abilities, } \\ \text { understanding } \\ \text { deficiencies and receiving } \\ \text { joyfully, convinced that by } \\ \text { apologizing in advance } \\ \text { would improve the } \\ \text { situation. }\end{array}$

The table above explains that self-confidence before content service actions with role playing techniques for fourth semester students with a percentage of $50 \%$

Table 4: Frequency Distribution of Initial Confidence in Post Test Results

\begin{tabular}{cccc}
\hline $\begin{array}{c}\text { Interval percentage } \\
\text { score }\end{array}$ & $\mathbf{F}$ & $\%$ & Criteria \\
\hline $90 \%-100 \%$ & 1 & 83,3 & Very good \\
$70 \%-80 \%$ & 9 & 75 & Well \\
$50 \%-60 \%$ & 0 & 0 & Enough \\
$30 \%-40 \%$ & 0 & 0 & Bad \\
$10 \%-20 \%$ & 2 & 16,6 & Very bad \\
Jumlah & 16 & 100 &
\end{tabular}

The table above shows that after experiencing content mastery services with the role playing technique the image of female students' confidence is in the very high category with a percentage of $6.25 \%$ or 1 female student, high category with a percentage of $83.3 \%$, a 
number of 9 female students and a moderate category with $75 \%, 2$ students with a percentage of $16.6 \%$.

Table 5: Average Student Confidence Post Test Results per Indicator

\begin{tabular}{|c|c|c|c|}
\hline No & Indicator & Percent & Criteria \\
\hline 1 & $\begin{array}{l}\text { Self-confidence in the } \\
\text { ability to complete college } \\
\text { assignments without } \\
\text { looking at friends' } \\
\text { answers, confident in } \\
\text { acknowledging mistakes } \\
\text { that have been made. }\end{array}$ & $74 \%$ & Enough \\
\hline 2 & $\begin{array}{l}\text { Fostering an optimistic } \\
\text { attitude so as not to } \\
\text { overcrowd in class, able to } \\
\text { do the task by believing in } \\
\text { one's own abilities, } \\
\text { understanding } \\
\text { deficiencies and receiving } \\
\text { joyfully, convinced that by } \\
\text { apologizing in advance } \\
\text { would improve the } \\
\text { situation. }\end{array}$ & $81 \%$ & Enough \\
\hline
\end{tabular}

\section{CONCLUSION AND CONCLUSION}

Through this research, results were found through content services with the role playing technique in the fourth semester that students' confidence in the fourth semester before experiencing the action was in the sufficient category. However, after experiencing content service actions with role playing techniques, students in the fourth semester experienced a significant increase in self-confidence. It can be concluded that the efforts made to increase self-confidence through content services with role playing techniques can significantly improve student confidence.

\section{REFERENCES}

[1] Fitri, E., Zola, N., \& Ifdil, I. (2018). Profil Kepercayaan Diri Remaja serta Faktor-Faktor yang Mempengaruhi. JPPI (Jurnal Penelitian Pendidikan Indonesia), 4(1), 1-5.

[2] Kushartanti, A. (2009). Perilaku menyontek ditinjau dari kepercayaan diri. Indigenous: Jurnal Ilmiah Psikologi, 11(2).

[3] Numri, M. Z. (2015). Meningkatkan Kemandirian Belajar Melalui Layanan Penguasaan Konten dengan Teknik Latihan Saya Bertanggungjawab. Jurnal Penelitian Tindakan Bimbingan \& Konseling, 1(1).

[4] Ilahi, R., Syahniar, S., \& Ibrahim, I. (2013). Faktor yang Mempengaruhi Pelanggaran Disiplin Siswa dan Implikasinya Terhadap Layanan Bimbingan \& Konseling. Konselor, 2(2).

[5] Baroroh, K. (2011). Upaya meningkatkan nilai-nilai karakter peserta didik melalui penerapan metode role playing. Jurnal Ekonomi dan Pendidikan, 8(2).

[6] Awlawi, A. H. (2013). Teknik Bermain Peran pada Layanan Bimbingan Kelompok untuk Meningkatkan Self-Esteem. Konselor, 2(1).

[7] Hurlock, E.B. 2013. Edisi ke Enam Perkembangan Anak (Jilid 1). Jakarta :Erlangga. 2012. Psikologi Perkembangan. Jakart:Erlangga

[8] Jarvis, Lori dkk. 2002. Role-Playing as a Teaching Strategy. Journal. Strategies for Application and Presentation Staff Development and Presentation.

[9] Sandtrock. J. W. 2003. Adolesence. Jakarta : Erlangga. 2010. Life-Span Development (Perkembangan Masa Hidup) Jilid 1. Jakarta : Erlangga
[10] Sukardi, D.K. 2008. Pengantar Pelaksanaan Program Bimbingan dan Konseling di Sekolah. Jakarta: Rineka Cipta.

[11] Tohirin, M. 2008. Bimbingan dan Konseling di Sekolah dan Madrasah Berbasis Integrasi. Jakarta: Rajawali Press.

[12] Prayitno. 2004. Layanan Bimbingan dan Konseling (L4). Jurusan Bimbingan dan Konseling Fakultas Ilmu Pendidikan Universitas Padang.

\section{AUTHORS PROFILE}

I am Melda Rumia Rosmery Simorangkir, and my affiliation is Bachelor's Degree Lecturer in Guidance and Counseling Study Program, Teaching and Education Faculty, Christian University of Indonesia. My area of interest in Counseling. 